\title{
Pemberdayaan Masyarakat di Tengah Pandemi COVID-19 melalui Pembuatan Sabun Cuci dari Minyak Jelantah sebagai Upaya Mengurangi Pencemaran Lingkungan
}

\author{
Uswatun Chasanah $^{1}$, Aulia Nursyifa ${ }^{2}$, Juhaeri $^{3}$, Imam Sofi' ${ }^{4}$ \\ Universitas Pamulang, Jl. Surya Kencana No.1, Pamulang Bar., Kec. Pamulang, Kota Tangerang \\ Selatan, Banten 15417 \\ Email: dosen02021@unpam.ac.id ${ }^{1}$
}

\begin{abstract}
ABSTRAK
Ditengah Pandemi COVID-19 membuat masyarakat melakukan berbagai aktivitas di dalam rumah, sehingga menimbulkan kejenuhan terutama ibu rumah tangga. Oleh karena itu, diperlukan berbagai aktivitas yang dapat dilakukan di rumah, salah satunya dengan memberdayakan ibu rumah tangga dalam pembuatan sabun cuci dari minyak jelantah. Tujuan dari pengabdian kepada masyarakat ini adalah untuk memberdayakan masyarakat dalam upaya mengurangi pencemaran lingkungan oleh limbah minyak jelantah. Metode pengabdian kepada masyarakat adalah memberikan penyuluhan kepada masyarakat melalui aplikasi zoom di komunitas masyarakat Puri Mawar Tangerang Banten. Hasil dari pengabdian kepada masyarakat ini ialah seluruh peserta memahami materi tentang pembuatan sabun cuci dari minyak jelantah, adanya peningkatan keterampilan masyarakat dengan cara mempraktekan pembuatan sabun cuci dari minyak jelantah, selain itu peserta sangat antusias untuk berdiskusi tentang berbagai upaya inovatif yang dapat dilakukan ibu rumah tangga dalam mengurangi pencemaran lingkungan. Pemberdayaan masyarakat ini sangat bermanfaat bukan hanya mengurangi pencemaran lingkungan dari limbah rumah tangga, tetapi dapat meningkatkan pendapatan masyarakat karena sabun cuci yang dihasilkan dapat diperjual belikan.
\end{abstract}

Kata kunci: Pemberdayaan; COVID-19; Sabun Cuci; Minyak jelanta; pencemaran lingkungan

\begin{abstract}
During the COVID-19 pandemic, people do various house activities, resulting in saturation, especially housewives. Therefore, various activities can be done at home, one of which is empowering housewives to manufacture laundry soap from barley oil. This community service aims to empower the community to reduce environmental pollution by jelantah oil waste. The community service method is to provide counseling to the community through zoom application in the puri mawar community Tangerang Banten. The result of this community service is that all participants understand the material about laundry soap from barley oil. There is an improvement in people's skills by practicing laundry soap from barley oil. Also, participants are very enthusiastic about discussing various innovative efforts that housewives can make in reducing environmental pollution. This community empowerment helps reduce environmental pollution from household waste and increase people's income because it can trade the resulting laundry soap.
\end{abstract}

Keywords: Empowerment; COVID-19; Laundry Soap; Jelanta oil; environmental pollution

\section{PENDAHULUAN}

Sejak keberadaan COVID-19 di Indonesia membuat masyarakat dianjurkan untuk tetap berada dirumah. Sebagaimana yang diintruksikan dalam Peraturan Pemerintah 
Nomor 21 Tahun 2020 Pasal 4 Tentang Pembatasan Sosial Berskala Besar dalam Rangka Percepatan Penanganan Corona Virus Disease 2019, bahwa pembatasan sosial di sekolah dan tempat kerja; keagamaan; dan di fasilitas umum (Pemerintah Republik Indonesia, 2020). Berdasarkan peraturan tersebut, membuat masyarakat melakukan berbagai aktivitas di dalam rumah untuk menekan penyebaran Virus COVID-19. Melakukan berbagai kegiatan di rumah terkadang membuat kejenuhan bagi masyarakat, terutama para ibu rumah tangga dengan berbagai pekerjaan rumah tangga yang semakin banyak dengan berbagai peran ganda yang dilakukan terutama mengatur keuangan ditengah pandemi karena penghasilan keluarga yang berkurang. Hal itulah yang membuat ibu rumah tangga harus memiliki inovasi dan kreativitas dalam mengisi waktu dirumah dan dapat menghasilkan masukan keuangan keluarga. Salah satu cara yang dapat dilakukan dengan memberdayakan masyarakat untuk membuat sabun cuci dari bahan limbah rumah tangga minyak jelantah sehingga dapat bernilai ekonomis.

Para ibu rumah tangga kerapkali menggoreng makanan dalam jumlah besar, mengganti minyak sekali pakai tidak selalu praktis dari sudut pandang ekonomis sehingga penggunaan minyak goreng dipakai berulang kali. Hasil dari penggunaan minyak goreng yang dilakukan berulang kali hingga keruh disebut dengan minyak jelantah. Penggunaan minyak jelantah untuk menggoreng makan dapat memberikan efek buruk bagi kesehatan. Pemanasan yang terjadi berulangkali dapat membuat minyak goreng berubah komposisinya karena dapat meningkatkan asam lemak bebas yang dapat menjadi racun bagi tubuh manusia.

Para ibu rumah tangga biasa menggunakan minyak goreng bekas pakai secara berulangkali untuk memasak. Padahal penggunaan minyak jelantah secara berulangkali sangat berbahaya bagi kesehatan sebagaimana yang diungkapkan dalam penelitian Ardhany dan Lamsiyah (2018) bahwa minyak jelantah yang digunakan terus menerus akan membahayakan bagi tubuh manusia, karena mengandung asam lemak jenuh yang sangat tinggi sehingga dapat memicu munculnya berbagai penyakit berbahaya, seperti penyakit hipertensi, stroke, jantung, bahkan dapat memicu terjadinya kanker yang berujung pada kematian.

Bahaya yang ditimbulkan dari penggunaan minyak jelantah bukan hanya dapat berbahaya bagi tubuh manusia, tetapi juga berbahaya untuk ekosistem lingkungan hidup. Masyarakat biasanya membuang minyak jelantah secara sembarangan ke saluran air sehingga dapat mencemari sungai dan bermuara ke lautan. Keberadaan minyak di lautan dapat menutupi permukaan air sehingga menghalangi masuknya sinar matahari dan 
oksigen, padahal keberadaan matahari dan oksigen sangat dibutuhkan bagi ekosistem makhluk hidup yang ada di laut, ditambah lagi dengan keberadaan minyak akan disukai bakteri yang dapat berbahaya bagi manusia karena menimbulkan berbagai penyakit.

Berdasarkan latar belakang tersebut, menginisiasi tim pengabdi untuk membuat kegiatan dengan tujuan untuk memberikan solusi untuk memberikan pemahaman kepada masyarakat akan limbah rumah tangga yakni minyak jelantah yang bisa dimanfaatkan menjadi sabun cuci, dengan adanya pengabdian masyarakat ini dapat berupaya memberdayakan masyarakat sekitar dalam mengurangi pencemaran lingkungan oleh limbah minyak jelantah.

\section{METODE}

Kegiatan pengabdian kepada masyarakat ini menggunakan metode penyuluh kepada masyarakat dengan menggunakan aplikasi zoom. Adapun saat pelaksanaan PkM memberikan informasi dan keterampilan dalam pembuatan sabun cuci dari minyak jelantah. Pelaksanaan Pengabdian kepada Masyarakat dilakukan pada komunitas Puri Mawar, jumlah peserta sebanyak 25 orang. Tempat pengabdian masyarakat dilakukan pada Komunitas Puri Mawar berada di Perumahan Puri Pamulang Tangerang Selatan Banten. Kegiatan pengabdian kepada masyarakat ini dilakukan pada bulan Juli 2020.

Adapun bahan-bahan yang dipersiapkan dalam kegiatan pengabdian kepada masyarakat ini yaitu:

1. Minyak Jelantah 500 gram

2. Natrium Hidroksida $(\mathrm{NaOH}) 64$ gram atau soda api

3. Arang Kayu

4. Air sebanyak $190 \mathrm{gr}$

5. Pandan atau sereh sebanyak 7-10 lembar.

Bahan-bahan yang diperlukan dalam membuat sabun cuci minyak jelantah dapat dilihat pada gambar 1 . 


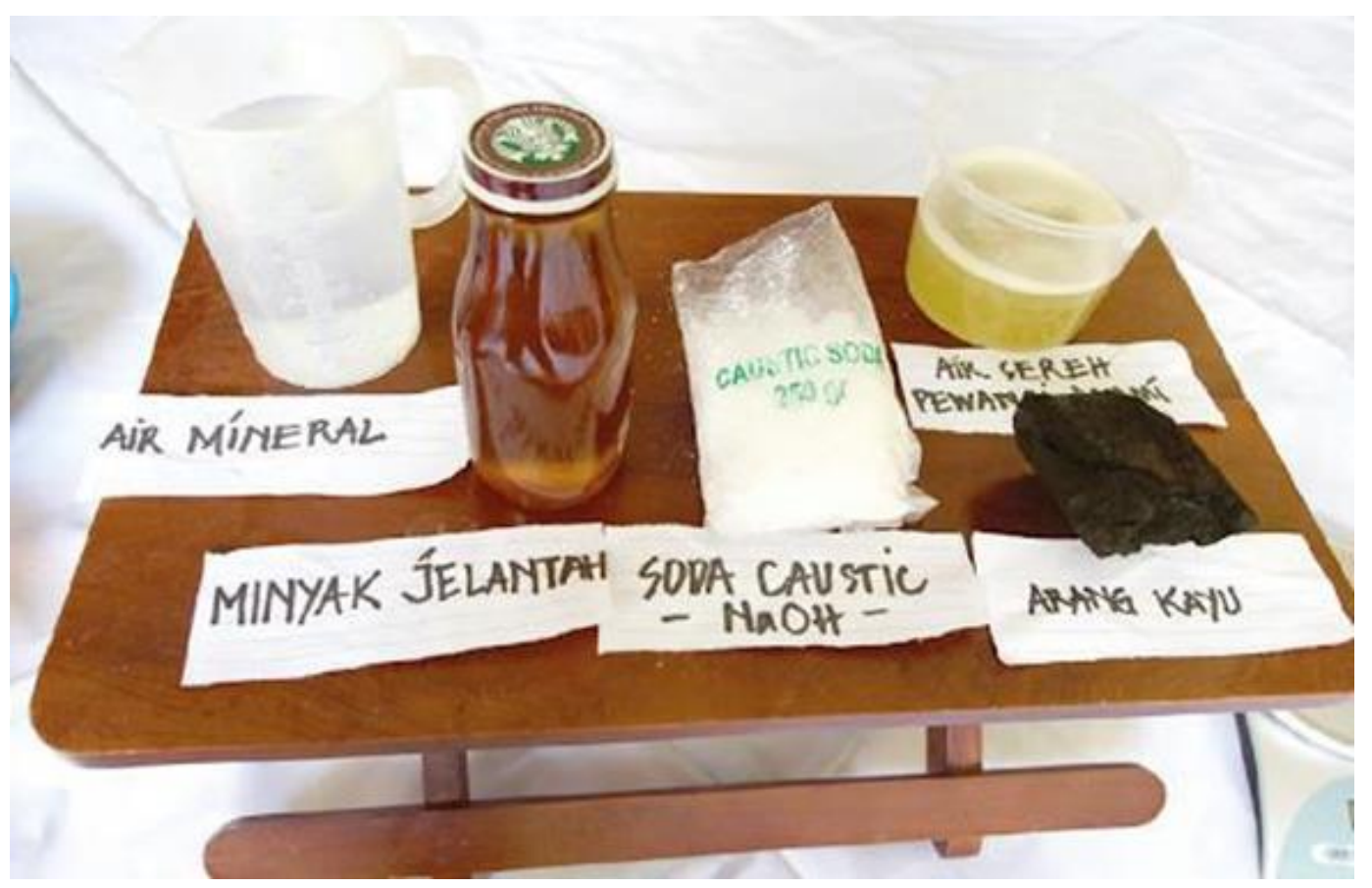

Gambar 1. Bahan - Bahan Untuk Membuat Sabun Cuci Minyak Jelantah Sumber: Dokumentasi penulis, 2020

Adapun alat-alat yang dapat digunakan dalam pembuatan sanbun cuci minyak jelantah yaitu:

1. Pengaduk kayu

2. Gelas takar

3. Wadah stainless steel yang tahan panas

4. Cetakan tahan panas

5. Timbangan

6. Lap yaitu:

Alat pengaman yang dapat digunakan dalam pembuatan sabun cuci minyak jelantah

1. Masker

2. Sarung tangan

3. Kacamata

Adapun yang yang perlu diperhatikan dalam pembuatan sabun cuci dari menyak jelantah ini yaitu:

1. Tidak menggunakan alat-alat berbahan alumunium, karena bahan almunium akan bereaksi dengan zat kimia $\mathrm{NaOH}$ sehingga akan menghasilkan gas Hidrogen menimbulkan ledakan atau menimbulkan gas. 
2. Dalam pembuatan sabun cuci dari minyak jelantah menggunakan alat pengaman agar zat kimia tidak terkena mata atau kulit.

Langkah-langkah pembuatan sabun cuci minyak jelantah dapat dijelaskan sebagai berikut:

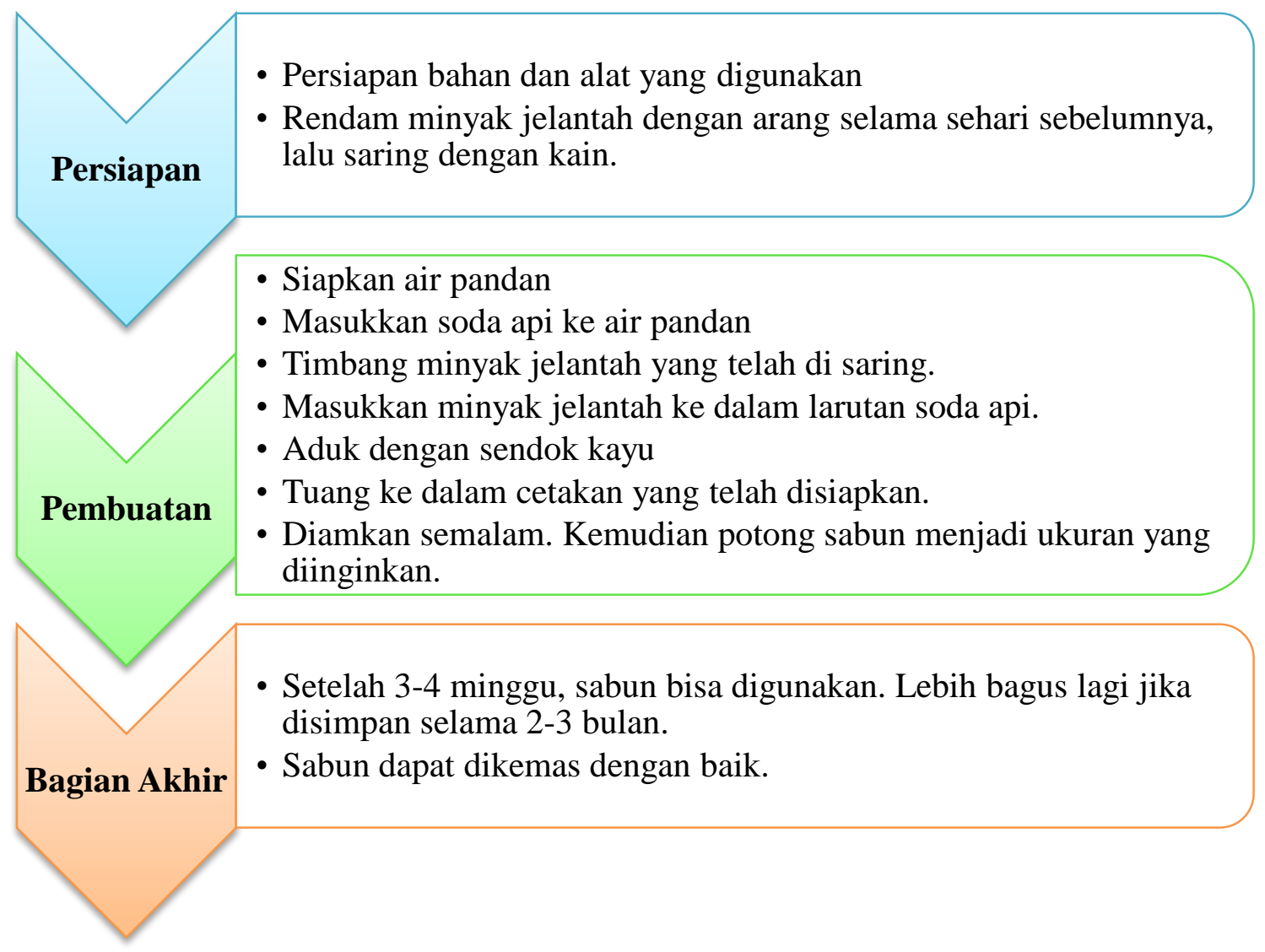

Gambar 2. Langkah-langkah Pembuatan Sabun Cuci Minyak Jelantah Sumber: Dokumentasi penulis, 2020

\section{HASIL, PEMBAHASAN, DAN DAMPAK}

Hasil dari kegiatan pengabdian kepada masyarakat pembuatan sabun cuci dari minyak jelantah terbukti dapat memberdayakan masyarakat terutama para ibu rumah tangga yang tergabung dalam komunitas Puri Mawar. Setelah diberikan penyuluhan tentang pembuatan sabun cuci dari minyak jelantah, para ibu rumah tangga mampu memahami penjelasan dari tim dosen pengabdi tentang pembuatan sabun cuci dari minyak jelantah.

Berikut ini dokumentasi kegiatan pengabdian kepada masyarakat yang ditunjukkan pada gambar 3 . 


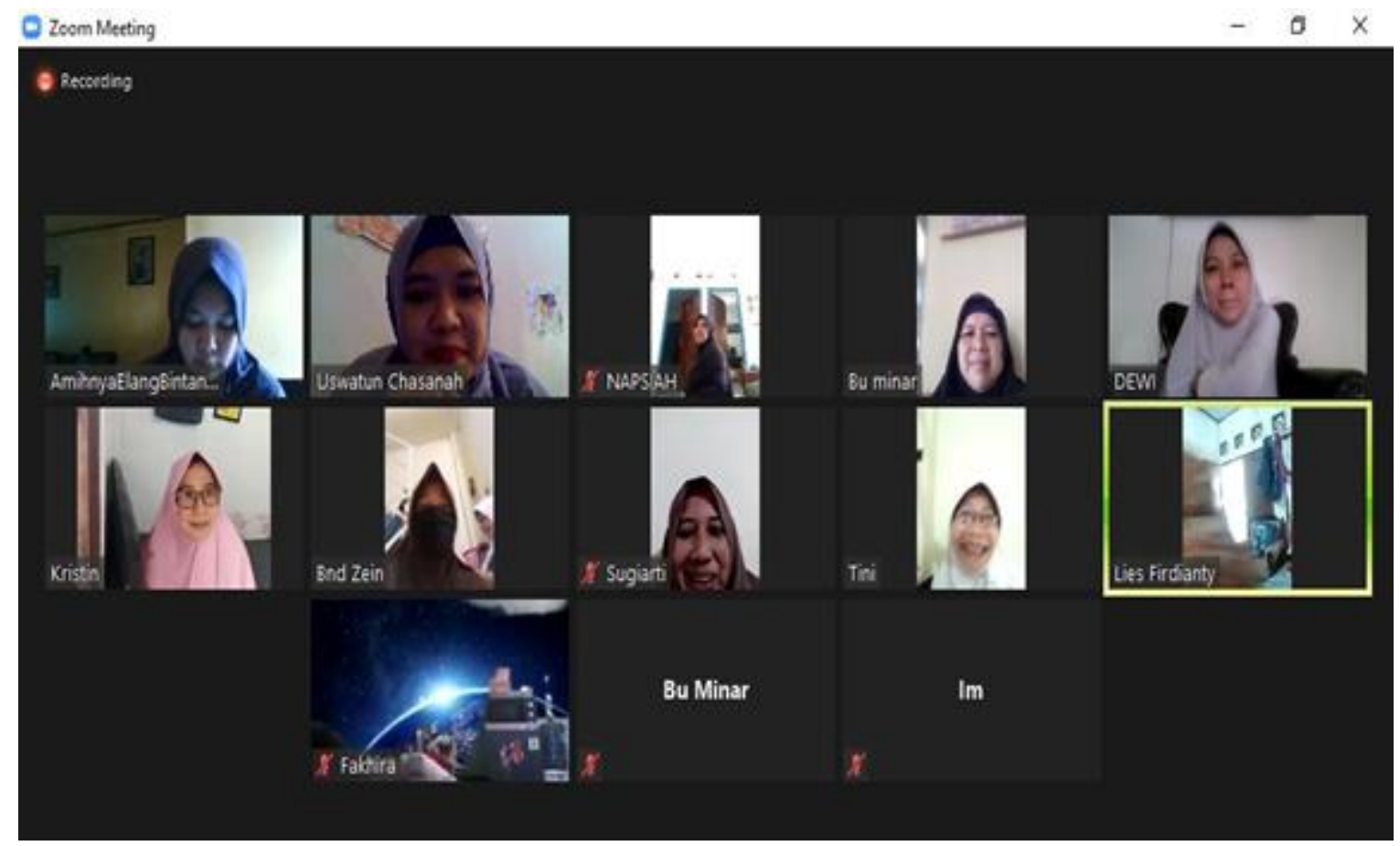

Gambar 3. Pelaksanaan Kegiatan PkM Melalui Aplikasi Zoom Sumber: Dokumentasi penulis, 2020

Berdasarkan gambar 3 menunjukkan para peserta terlihat antusias dalam mengikuti kegiatan penyuluhan dengan berperan aktif berdiskusi dengan tim dosen pengabdi, sehingga memberikan pemahaman tentang dampak negatif dari minyak jelantah yang tidak hanya mengganggu kesehatan tetapi juga merusak lingkungan hidup. Kesadaran ibu rumah tangga akan bahaya minyak jelantah memberikan suatu perubahan untuk merubah kebiasaan lama membuang minyak jelantah habis pakai ke saluran air, dengan cara mengumpulkan minyak habis pakai tersebut untuk didaur ulang sehingga dapat mencegah pencemaran lingkungan akibat limbah rumah tangga. Dengan adanya pembuatan sabun dari minyak jelantah sebagai bentuk inovatif yang dapat dilakukan ibu rumah tangga dalam mengurangi pencemaran lingkungan disekitar tempat tinggalnya.

Selain itu, para ibu rumah tangga tidak hanya mendapatkan pengetahuan tentang mendaur ulang minyak jelantah untuk dijadikan sesuatu yang bermanfaat. Tetapi juga memiliki keterampilan untuk mempraktekan pembuatan sabun cuci dari minyak jelantah, Pemberdayaan masyarakat ini sangat bermanfaat bukan hanya mengurangi pencemaran lingkungan dari limbah rumah tangga, tetapi dapat meningkatkan pendapatan masyarakat karena sabun cuci yang dihasilkan dapat diperjual belikan.

Ditengah pandemi seperti saat ini masyarakat membutuhkan lingkungan sekitar yang bersih untuk mencegah dari penyebaran virus COVID-19. Namun disisi lain, masyarakat saat ini dituntut memiliki kreativitas untuk mengisi waktu dirumah dengan 
berbagai aktivitas yang bermanfaat salah satunya pembuatan sabun cuci dari minyak jelantah. Minyak jelantah dapat diolah menjadi produk yang bermanfaat sehingga dapat mengendalikan pencemaran lingkungan (Kusumaningtyas dkk, 2018) dan dapat dimanfaatkan dengan baik akan bernilai ekonomis (Chandra dkk, 2020). Berbagai contoh inovasi yang dapat bermanfaat dari daur ulang minyak jelantah diantaranya: minyak jelantah dapat dibuat menjadi biodesel (Ahmadi dan Prasetya, 2016; Hadrah, Kasman, dan Sari, 2018; Fitria, Trisnaliani, dan Purnamasari, 2018); masyarakat dapat diperdayakan dengan membuat minyak jelantah menjadi sabun hias (Nisyak dan Amanda, 2019; Suwartini, Erviana, dan Mudayana, 2018); minyak jelantah dapat dijadikan sebagai pengharum ruangan (Dwitiyanti dan Suharmanto, 2020); minyak jelantah dapat menjadi produk sabun pembersih lantai (Sumiati dkk., 2019); minyak jelantah juga dapat dimanfaatkan sebagai sabun pencuci tangan (Erviana, 2019); dan banyak manfaat lainnya. Berdasarkan hasil penelitian dan pengabdian kepada masyarakat yang telah dilakukan sebelumnya menjadi bukti bahwa banyak manfaat yang dapat dihasilkan dari mendaur ulang minyak jelantah bagi kehidupan masyarakat tidak hanya dapat meningkatkan penghasilan bagi masyarakat untuk berwirausaha ditengah pandemi namun juga dapat memberikan dampak untuk mencegah kerusakan lingkungan di sekitar masyarakat.

Dosen tim pengabdi mengevaluasi kegiatan pengabdian masyarakat ini, salah satunya dalam mempraktekkan secara langsung tidak hanya sebatas via aplikasi zoom tetapi pemberdayaan kepada masyarakat ini dilakukan secara berkelanjutan sampai menghasilkan produk yang dapat diperjualbelikan oleh masyarakat dan dipasarkan secara online. Oleh karena itu, dampak dari kegiatan pengabdian masyarakat ini dirasakan pada saat berlangsungnya kegiatan pengabdian masyarakat dengan adanya peningkatan pemahaman peserta tentang pembuatan sabun cuci dari minyak jelantah, tetapi dampak kegiatan masyarakat ini dapat dirasakan para peserta dengan memiliki keterampilan dalam pembuatan sabun cuci minyak jelantah.

\section{SIMPULAN}

Setelah mengikuti kegiatan pengabdian kepada masyarakat ini, para ibu rumah tangga yang tergabung pada komunitas puri mawar mendapatkan pemahaman akan pengolahan limbah rumah tangga yakni minyak jelantah yang bisa dimanfaatkan menjadi sabun cuci. Masyarakat sangat antusias mengikuti kegiatan pengabdian kepada masyarakat. Para ibu rumah tangga juga mendapatkan keterampilan dalam pembuatan sabun cuci berbahan dasar minyak jelantah. Berdasarkan kemampuan mendaur ulang 
minyak jelantah dapat meningkatkan inovasi dan memberikan kesejahteraan keluarga di tengah pandemi.

\section{DAFTAR PUSTAKA}

Ahmadi, dan Prasetya, D. S. B. (2016). Ipteks Bagi MasyarakatPengolahan Minyak Jelentah Menjadi Biodiesel di Tanjung Karang Kota Mataram. Lumbung Inovasi: Jurnal Pengabdian Kepada Masyarakat, 1(1), 10-12.

Ardhany, S. D., dan Lamsiyah. (2018). Tingkat Pengetahuan Pedagang Warung Tenda Tentang Bahaya Penggunaan Minyak Jelantah Bagi Kesehatan. Jurnal Surya Medika, 3(2).

Chandra, Asrinawaty, Fauzan, A., dan Agustina, N. (2020). Pelatihan Pembuatan Daur Ulang Minyak Jelantah Berbasis Ecogreen di Rumah Singgah Yatim dan Dhuafa Kota Banjarbaru. Jurnal Abdimas Kesehatan, 2(1), 69-75. https://doi.org/10.36565/jak.v2i1.98

Dwitiyanti, N., dan Suharmanto, P. (2020). Pemanfaatan Minyak Bekas Pakai Untuk Pengharum Ruangan. Logista Jurnal IlmiahPengabdian KepadaMasyarakat, 4(1), 98-103.

Erviana, V. Y. (2019). Pelatihan pengolahan minyak jelantah menjadi sabun, strategi pemasaran di desa Kemiri. Jurnal Pemberdayaan: Publikasi Jasil Pengabdian Kepada Masyarakat, 3(1), 17-22.

Fitria, Trisnaliani, L., dan Purnamasari, I. (2018). Pelatihan pembuatan biodiesel minyak jelantah skala laboratorium di SMP Negeri 5 Pangkalan Panji Banyuasin Sumatera Selatan. Aptekmas; Jurnal PengabdianKepada Masyarakat, 1(2), 3-6.

Hadrah, Kasman, M., dan Sari, F. M. (2018). Analisis Minyak Jelantah Sebagai Bahan Bakar Biodiesel Proses Transesterifikasi. Jurnal Daur Lingkungan, 1(1), 16-21.

Kusumaningtyas, R. D., Qudus, N., Putri, R. D. A., dan Kusumawardani, R. (2018). Penerapan teknologi pengolahan limbah minyak goreng bekas menjadi sabun cuci piring untuk pengendalian pencemaran dan pemberdayaan masyarakat. ABDIMAS, 22(2), 201-208.

Nisyak, K., dan Amanda, E. R. (2019). Pemberdayaan Masyarakat Desa Balongbendo Sidoarjo Melalui Pelatihan Pembuatan Sabun Hias Minyak Jelantah. Seminar Nasional Hasil Riset Dan Pengabdian. Surabaya: Universitas PGRI Adi Buana.

Pemerintah Republik Indonesia. Pembatasan Sosial Berskala Besar dalam Rangka Percepatan Penanganan Corona Virus Disease 2019 (COVID-19)., (2020).

Sumiati, Munandar,T.A, Febriasari, A, Suryaman, Sulasno, dan Dwijayanti, A. (2019). Pemberdayaan Kelompok Ibu Rumah Tangga Melalui Pembentukan Home Industry Sabun Pencuci Lantai Berbahan Dasar Limbah Minyak Jelantah. AL-Khidmat, 2(1), 29-33.

Suwartini,I., Erviana., V. Y., dan MUdayana, A. (2018). Strategi Pemasaran Hasil Olahan Limbah Minyak Jelantah dan Limbah Kulit Pisang Menjadi Sabun Souvenir di Desa 
Sendangsari. Syukur: Jurnal Inovasi Sosial Dan Pengabdian Kepada Masyarakat, 1(2), 125-131. https://doi.org/10.22236/syukur 